\title{
PERFORMANCE EVALUATION OF SELECTED MICROFINANCEINSTITUTIONS OPERATING IN NEW DELHI, INDIA
}

\author{
Kanishka Sethi a, Dr. Reshma Nasreen b, Dr. Matloobullah Khan c \\ abc Jamia Hamdard University, New Delhi, India \\ Corresponding email: kanishkasethi.sch@jamiahamdard.ac.in
}

\begin{abstract}
The Microfinance Institutions operating in New Delhi, India are still in their infancy stage. The performance of Institutions is dismal and awareness among the marginalized section is minimum. Thus, primary data on selected Microfinance Institutions (MFIs) operating in New Delhi has been collected and analyzed to evaluate the performance of the institutions. For the selected case situations of chosen NBFC-MFIs, cross comparison among the institutions would help us conclude the best operating MFI and grade all others. Relevant suggestions for other institutions would be provided.
\end{abstract}

Keywords: Microfinance, Microfinance Institutions, Performance Evaluation.

\section{Introduction}

Micro Finance is the provision of credit and other financial services to the poorest of the poor. These needy people have been out-rightly secluded from the formal financial sector due to non-possession of collaterals with them. They form the majority of the population in any developing country, including India. Thus, it becomes customary to cater to their credit requirements for a holistic development of the nation. In such an environment, Micro Finance Institutions (MFIs) and other similar lending agencies have evolved to provide micro credit for short duration to this needy group. The loans are mostly collateral free and provided at high rates of interest to cover the high operating costs of the institutions. Such institutions provide hopes of a poverty free nation to many. Such ideology has been initiated by Muhammad Yunus, who received Nobel Peace Prize in 2006 for forming Grameen Bank and coining the concepts of Micro credit and Micro finance. According to him, Micro Finance- extension of small amounts of collateral free loans to jointly liable poor group members for self-employment and income generation- has become a major tool of promoting inclusive growth and sustainable development.

The Micro Finance Industry is unique in nature due to its double bottom line objective of Outreach (reaching large number of poor) and Sustainability (ability to cover costs and earn profits in the long run). Thus, the strategies followed by other industries cannot be replicated to the Micro Finance Industry. The Micro Finance Institutions have been operating for quite long now, but fail to address the problems of the poor and sustain themselves in the long run. Such a scenario is more prevalent in the Northern region of the country, particularly Delhi. The reasons for their ultimate failure are varied. The institutions lack foresightedness, professional staff, Government support, appropriate financial policies, sound and strict repayment mechanisms; and adequate monitoring of client base, technology, infrastructure and the like. By keeping these facts in mind, I have chosen the topic 'Performance Evaluation of Microfinance Institutions in New Delhi, India' to understand the overall performance of the Industry in the capital of the country. 


\section{Review of Significant Literature}

Agarwal Swati, (2009) in her research paper has highlighted the dismal state of the Micro Finance sector in the capital of the country due to negligible efforts of the State and Central Government. The different schemes initiated by Delhi Government for urban poor shows numerous steps taken by the government, but the inadequate cash outlay for the sector in every consecutive Budget speaks a different story altogether. The corrupt implementation of various schemes in numerous departments makes Micro Finance an illusion in the capital up till date. Our attention has been drawn towards the efforts taken by the South Indian States in the field of Micro Finance which the Delhi government needs to learn and incorporate in its functioning.

Copestake, 2007, in his research paper, showed that the entire chosen sample set of MFIs performed satisfactory on both social and financial performance indicators, but there was still scope for improvement. It has been suggested that better strategic planning, routine monitoring of clients, periodic review of activities undertaken can significantly help the MFIs manage their social and financial performances better and reduce mission drift. Emeni, (2008)paper discussed a lot of factors for the dismal state of MFIs in the country, Nigeria. The MFIs have been requested to tap the local and international capital markets to raise funds for their clients and expand their institutions. It is believed that the MFIs need to study the lending and working mechanisms of the prevalent and well established money lenders in the area which can help them expand their industry rapidly. Wijesiri, Vigano and Meoli, (2015) observed that none of the MFIs in the chosen dataset performed well on both dimensions of efficiency i.e. financial and social. While the Age of MFIs and Degree of Capitalization was found to be significant indicators of financial efficiency. On the other hand, Age of MFIs, type of institution and Return on Asset as an indicator of profitability are found to be crucial indicators of social efficiency

\section{Research Method and Research objectives}

The primary sources of data would include all the NBFC-MFIs registered with Reserve Bank of India (RBI) and operating in New Delhi. The selected MFIs include: Altura Financial Services Limited, Capital Trust Limited, Fusion Microfinance, Satin Credit care Network Limited, Saija Finance Private Ltd, Shikhar Microfinance and S V Credit line Pvt Ltd.

Based on the systematic and comprehensive review of the empirical and theoretical literature on the microfinance institutions, the following objectives have been laid down:

1. To analyze the performance of the selected NBFC-MFI registered with RBI and operating in Delhi;

2. To cross compare the selected micro finance institutions with each other on the basis of size;

3. To grade the institutions on the basis of their financial performance.

\subsection{Hypothesis for Objective No 1:}

Ho: There is no significant difference in the performance of selected micro finance institutions based upon their categorization of size.

To analyze the financial performance of the selected micro finance institutions, qualitative descriptive research methodology has been used. The study uses three major financial performance indicators, viz: loan quality, operational efficiency and portfolio quality. The following variables are assumed to gauge the performance of the selected micro finance institutions given the performance indicators:

Loan Quality:

1. Average loan per borrower;

2. Loan disbursed to gross loans;

3. Proportion of defaulted accounts;

Operational Efficiency:

1. Manager to field staff ratio;

2. Field staff per branch; 
3. Rate of interest;

4. Average loan per field staff.

Portfolio Quality:

1. Portfolio at risk $>30$ days

2. Portfolio at risk $>90$ days.

To test the hypothesis, we have used dummy regression model to capture the effect of the size of the micro finance institution on the given financial performance variables. The number of branches of the micro finance institution has been used as proxy for categorization of the sample micro finance institutions into two categories, viz, big and small. In all, nine bivariate regressions are run to investigate whether size has any role in explaining the variation in the chosen variables that are assumed to measure different indicators of financial performance. The Dummy variable in our model takes the value ' 1 ' if the size of the institution is big, else 'o', when the size of the institution is small. Further, the study uses a ranking method for evaluating the performance of the sample institutions on the basis of different financial performance indicators and on overall basis. The scale ranges from 1 to 7 , with ' 1 ' reflecting the best ranking and the ' 7 ' the poor or worst ranking.

\section{Profile of Selected Microfinance Institutions Altura Financial Services Limited}

Altura Financial Services Limited is a NBFC -MFI registered with RBI to provide micro finance services to the under-served rural and semi-urban women across the nation. The institution is currently operational in 7 states of our country to reach the under-served section of our society. JLG loans are provided by the organization for income generating purposes which include loans for agriculture, cattle, materials, dairy, small scale businesses etc. The loan tenure ranges from 12 months to 24 months to support the income generating and repayment capacity of the borrowers. Maximum of Rs. 50000 has been dispersed as group loan to clients for repayment of pre-calculated installments. The institution charges interest rate of $24.91 \%$ p.a. from its clients on reducing balance. Regular trainings are provided and workshops conducted to equip the clients with necessary resources, skills and vision to transform their small businesses into profitable entities. The company has even tied up with Life Insurance Corporation (LIC) to provide credit life insurance to its clients. Insurance covers the unfortunate event of death of borrower or spouse only to reimburse the appropriate loan amount to the family to reduce the debt burden.

\subsection{Capital Trust Limited}

Capital Trust Limited was incorporated in 1985 and has been working as a NBFC for over 30 years in the financial services industry. In 2008, after abandoning its operations in the prior Consultancy Services, the institution ventured into the foray of micro finance. Thus, capital trust became one of the few companies to span in the areas of both micro finance and MSME Industry. Yogen Khosla is the current Managing Director of the company and was the one to introduce the company to retail lending of micro loans in the rural and semi-urban areas of the nation. Due to his great vision and focus, the company even entered the top 100 Small and Medium Enterprises in India list created by India SME Forum in 2017. The MFI provide individual and group loans to their clients for various income generating activities which include manufacturing, dairy and livestock, trading, services, food, retail and agriculture. Micro finance loans are provided for retail financing of products like two wheelers, consumer durables, office equipment etc. Mostly, known products are offered to the borrowers on 26 $\%$ rate of interest per annum and $1 \%$ processing fees. The institution is geographically present in 6 states and union territories spread across the Northern region of the country.

\subsection{Fusion Microfinance}

Fusion microfinance has been set up and registered as a NBFC- MFI in 2010. It operates according to the Joint Liability Group Model of Grameen Bank initiated by Nobel Prize Winner Professor Muhammad Yunus in Bangladesh. They focus on reaching out to hundred percent women client residing in rural and semi urban areas to provide financial services to them and convert them into successful women entrepreneurs. The marginalized women 
clients are engaged in various kinds of small businesses like transportation, carpentry, livestock, small shops etc. The household income of women clients residing in rural areas falls below Rs. 1,00,000 and Rs. 1,60,000 in urban areas. They have dispersed their operations to 14 States via 305 branches. Their Gross Loan Portfolio outstanding reaches out to be Rs. 960.55 crore out of which the cumulative loan amount disbursed amounts to Rs. 2567.66 crores. Every branch is set up and headed by a branch manager and 4-5 Relationship officers. The field officers visit the villages to familiarize themselves to the local villages and explain their operations to the prospective clients. The borrowers in most cases themselves from groups of 5 clients each and in total 3-6 groups form a centre. A three day Compulsory Group Training (CGT) is provided to the clients followed by a Group Recognition Test (GRT) undertaken by Branch Manager. Consequently, the loan disbursement is done at the branch premises. Various types of loan products are offered at Fusion like Income Generation, Top up, Emergency and Sanjivani. Repayment for various products is mostly weekly, fortnightly and monthly for the borrowers.

\subsection{Satin Creditcare Network Limited}

According to the issue 21 Micro-meter by Micro Finance Institution Network (MFIN), the company is reported to be the third largest micro finance institution in terms of its Gross Loan Portfolio. The institution started its operations in the year 1990 and registered itself as a Non Banking Finance Company (NBFC) with RBI in 1998. The main business is to provide jointly liable group loans to economically active women in rural and semi-urban areas. They also provide individual loans for small businesses particularly Micro Small and Medium Enterprises (MSMEs), product loans for purchase of solar lamps and developmental loans for water connection and sanitation facilities. The organization has spread its operations across 16 States and union territories with 634 branches in India which have moderate or low levels of penetration by other MFIs. It is one of the few MFIs to be listed with Calcutta Stock Exchange, National Stock Exchange and Bombay Stock Exchange for their equity shares. All the clients at SCNL are provided Compulsory Group Training (CGT) by the credit officers / field staff of the institution. Consequently, Group Recognition Test (GRT) is conducted on the clients to assess their genuine understanding towards the program and interest towards jointly sharing their loan. After the successful completion of GRT, credit is extended Collateral free to the clients in jointly liable manner. The institution provides different types of products and services according to the requirements and repayment capacities of their client. The first type of product offered is the income generating loan for various sub-sectors like animal husbandry, production, service and trade. Different amounts ranging from Rs. 5000 to Rs. 50000 are repayable in one, one and half hour and 2 years according to the income generation capacity of the borrowers. The second type of product offered is water and sanitation loan for rural and semi-urban clients facing problems of open defecation and drinking water. The Loan provides adequate water and sanitation facilities within their households. The third type of product is the solar loan for financing solar lanterns at affordable rates for the villages which are still not electrified. According to the CRISIL Report dated January 11, 2017 the institution has been assigned a fundamental grade of 3 out of 5 and a fair value of their share at Rs. 518 .

\subsection{Saija Finance Pvt. Ltd}

Saija is NBFC formed in 2007 and registered with RBI to provide micro finance to rural and urban poor spread in the Northern and Eastern regions of the country. Mr. S. K. Sinha is the Chairman cum Managing Director at Saija. Using his professional knowledge, experience and networking activities the institution has become one of the first to achieve Rs. 30 million worth of business. The institution has suitably modified the Grameen Bank Model into a more workable and practical JLG model. The borrowers voluntarily form a group of 5 to 6 members under the guidance and support of Saija Executive. After the formation of the group, compulsory group training include awareness of products and services offered by the Institution, policies and procedures followed, the concept of group guarantee and benefits of the model. Consequently, group recognition test is conducted to ensure understanding of the above mentioned concepts my all group members. Group meetings are weekly or fortnightly held to discuss social or community issues, communication of developmental changes, filling 
of loan application forms and collection of the payment amounts. The institution has spread its operations to 3 operational States through 64 branches and 37 districts. The institution offers 5 different kinds of products for its diversify clients namely Saija Karobar Rin (SKR), Saija Mahila Rin (SMR), Saija Vridhi Rin (SVR) and Saija Phone Rin (SPR). As the name suggests, the Karobar loan is provided to jointly liable 4 to 6 group members to provide financial assistance for their business Enterprises. The loan amount ranges from Rs. 10000 to Rs. 100000 for a weekly / fortnightly / monthly repayment according to paying capacity of the borrowers. The Mahila loan is loan grant to women to financially assist them in their income generating activities and genuine consumption needs. The loan amount ranges from Rs. 5,000 to Rs. 1, 00,000. Urja loan is a loan provided to clients to purchase solar lighting products for their households. The loan amount is Rs. 1899 and is payable in 13 fortnightly installments. Vridhi loan provide clients the facility to avail loans up to $75 \%$ of the main loan. The last product is the phone loan provided to transfer mobile phones to their clients on installments. The loan amount is Rs. 7,000 and the tenure of the loan being one year.

\subsection{Shikhar MicrofinancePvt. Ltd}

Shikhar Microfinance Pvt. Ltd. is a non-deposit taking Non- Banking finance company (NBFC-MFI) regulated by Reserve Bank of India (RBI). They provide financial services and livelihood opportunities to the un-bankable segment of the society. Their core services to the poor include income generating microfinance loans ranging from Rs. 15,000 to Rs. 80,000 repayable over a period of 12-36 months. The services empower the underprivileged to break the shackles of poverty, get rid of debt traps, initiate savings, provides better health, shelter, sanitation and education to their families. The institution follows the Joint Liability Group Model to provide micro-credit services to its economically backward clients. The current business summary snapshot of Shikhar Microfinance Pvt. Ltd as on $30^{\text {th }}$ April 2017 includes 41,990 active loans to their clients amounting to Rs. 59.4 crore in the form of Gross Loan Portfolio with the institution. Shikhar Microfinance has spread its operations to 26 branches and 168 working staff in its earnest endeavor to reach the underprivileged. The wide range of areas covered by Shikhar includes Delhi NCR Region, Uttrakhand, Haryana and Western Uttar Pradesh. The current rate of interest charged to its clients on active loans is $25.35 \%$. The clients are mostly those residing in slums, unauthorized colonies, rural and urban villages. Shikhar has even collaborated with two Third parties viz Samsung Electronics and Hindustan Unilever to move one level up in providing low cost products to their clients on voluntary basis. With the help of Samsung Electronics, the institution provides low cost smart phones to their customers at competitive prices and through Hindustan Unilever, water purifying devices are made available to their clients at affordable prices.

\subsection{S V CreditlinePvt. Ltd}

SVCL is a NBFC registered with RBI under section $451 \mathrm{~A}$ and has its corporate office in Gurugram (Haryana). It started its micro finance operations in January 2010 to establish its strong presence in Northern and Central regions of the nation. Mr. Surinder Singh Kohli (Chairman and Independent director) has undertaken directorship in various Institutions before joining SVCL which includes IDFC, IIFCL, Reliance Infrastructure and BSES Yamuna and BSES Rajdhani Power Ltd. The institution targets women in rural areas with annual household income less than rupees one lakh and semi urban areas with household income less than rupees one lakh sixty thousand. These women are mostly engaged in income generating activities or intent to do so, but fail due to non access to financial services as they lack possession of collaterals. The loan amount is utilized for varied productive farm and non-farm activities like animal husbandry, trading, production etc. The institution follows the joint ability group model to form a group of 5 women bore well known to each other but not belonging to the same family. The business model of the organization follows the following steps: Villages and their prospective clients are identified by organizing projection meetings in the particular distressed area. Then, a group of 5 women borrowers is formed which undergo a three day training Program. Consequently, groups are joined to the centre and loans are granted to the group members for their income generating activities. After, successful repayment of first loan amount successive loans is granted to the borrowers to run 
their business and enhance their savings. Finally,after witnessing success stories of existing members, new clients even join the group and expand the network of the institution. The Institution offers three different kinds of loan products namely Unnati, Pragati and Samriddhi. Under Unnati, loan amount ranges from Rs. 10,000 to Rs. 15,000 repayable within one year of loan grant. Pragati offers loan amount for 2 years ranging from Rs. 16,000 to Rs. 26,000. The loan product, Samriddhi offers loan ranging from Rs. 27,000 to Rs. 35,000 . The rate of interest is $24.7 \%$ reducing balance for all loan products.

\section{MICRO FINANCE INSTITUTIONS: OVERVIEW}

\begin{tabular}{|c|c|c|c|c|c|c|c|}
\hline Parameters & Altura & Capital Trust & Fusion & Satin & Saija & Shikhar & $\begin{array}{l}\text { S V } \\
\text { Creditline }\end{array}$ \\
\hline History & $\begin{array}{l}\text { Received } \\
\text { NBFC-MFI } \\
\text { license in } \\
\text { the year } \\
2014 \text { and } \\
\text { started its } \\
\text { operations }\end{array}$ & $\begin{array}{l}\text { Capital Trust } \\
\text { Limited was } \\
\text { incorporated in } \\
1985 \text { and } \\
\text { ventured into } \\
\text { the foray of } \\
\text { micro finance } \\
\text { in } 2008 .\end{array}$ & $\begin{array}{l}\text { Set up and } \\
\text { registered as } \\
\text { a NBFC- MFI } \\
\text { in } 2010\end{array}$ & $\begin{array}{l}\text { Started } \\
\text { operations in } \\
1990 \text { and } \\
\text { registered } \\
\text { itself as } \\
\text { NBFC with } \\
\text { RBI in } 1998\end{array}$ & $\begin{array}{l}\text { Formed in } \\
2007 \text { and } \\
\text { registered } \\
\text { with RBI }\end{array}$ & $\begin{array}{l}\text { In } 2008 \text {, } \\
\text { Shikhar Trust } \\
\text { acquired a non- } \\
\text { deposit taking } \\
\text { NBFC to } \\
\text { undertake the } \\
\text { microfinance } \\
\text { operations of } \\
\text { Shikhar } \\
\text { Microfinance } \\
\text { Private Ltd. }\end{array}$ & $\begin{array}{l}\text { Registered } \\
\text { with RBI } \\
\text { under } \\
\text { section 451A } \\
\text { having } \\
\text { corporate } \\
\text { office in } \\
\text { Gurugram } \\
\text { (Haryana) }\end{array}$ \\
\hline Philosophy & $\begin{array}{l}\text { To facilitate } \\
\text { socio } \\
\text { economic } \\
\text { financial } \\
\text { inclusion of } \\
\text { distressed } \\
\text { families }\end{array}$ & $\begin{array}{l}\text { Encourage self- } \\
\text { sufficiency and } \\
\text { entrepreneursh } \\
\text { ip in the } \\
\text { unbanked } \\
\text { population of } \\
\text { the country }\end{array}$ & $\begin{array}{l}\text { Providing the } \\
\text { underprivileg } \\
\text { ed women } \\
\text { economic } \\
\text { opportunities } \\
\text { to transform } \\
\text { the quality of } \\
\text { their lives }\end{array}$ & $\begin{array}{l}\text { Catering to } \\
\text { the } \\
\text { financially } \\
\text { excluded } \\
\text { households } \\
\text { by being a } \\
\text { one stop } \\
\text { solution to } \\
\text { their } \\
\text { financial } \\
\text { needs }\end{array}$ & $\begin{array}{l}\text { To create } \\
\text { significant } \\
\text { social impact } \\
\text { through } \\
\text { high-quality } \\
\text { sustainable } \\
\text { microfinance }\end{array}$ & $\begin{array}{l}\text { Shikhar values } \\
\text { are popularly } \\
\text { referred to as } \\
\text { ICE-FEST. } \\
\text { (Integrity, } \\
\text { Credibility, } \\
\text { Excellence, } \\
\text { Fairness, } \\
\text { Enterprising, } \\
\text { Stewardship } \\
\text { and } \\
\text { Transparency.) }\end{array}$ & $\begin{array}{l}\text { To build a } \\
\text { professional } \\
\text { ly managed } \\
\text { and } \\
\text { sustainable } \\
\text { microfinanc } \\
\text { e institution }\end{array}$ \\
\hline Leader & $\begin{array}{l}\text { Ms. Mala } \\
\text { Kaur is the } \\
\text { Chief } \\
\text { Executive } \\
\text { Officer of } \\
\text { Altura and } \\
\text { handles its } \\
\text { day to day } \\
\text { operations }\end{array}$ & $\begin{array}{l}\text { Yogen Khosla is } \\
\text { the current } \\
\text { Managing } \\
\text { Director of the } \\
\text { company }\end{array}$ & $\begin{array}{l}\text { TarunMehnd } \\
\text { iratta is the } \\
\text { current Chief } \\
\text { Operating } \\
\text { Officer } \\
\text { (COO) at } \\
\text { Fusion }\end{array}$ & $\begin{array}{l}\text { HP Singh is } \\
\text { the Chairman } \\
\text { cum } \\
\text { Managing } \\
\text { Director at } \\
\text { Satin }\end{array}$ & $\begin{array}{l}\text { Mr. S. K. } \\
\text { Sinha is the } \\
\text { Chairman } \\
\text { cum } \\
\text { Managing } \\
\text { Director at } \\
\text { Saija }\end{array}$ & $\begin{array}{l}\text { Mr. Satyavir } \\
\text { Chakrapani is } \\
\text { the Managing } \\
\text { Director \& } \\
\text { Chief Executive } \\
\text { Officer at } \\
\text { shikhar }\end{array}$ & $\begin{array}{l}\text { Mr. } \\
\text { Surinder } \\
\text { Singh Kohli } \\
\text { is the } \\
\text { Chairman } \\
\text { and } \\
\text { Independen } \\
\text { t director of } \\
\text { the } \\
\text { institution }\end{array}$ \\
\hline $\begin{array}{l}\text { Business } \\
\text { Model }\end{array}$ & $\begin{array}{l}\text { Loan tenure } \\
\text { ranges from } \\
12 \text { months } \\
\text { to } 24 \\
\text { months. } \\
\text { Maximum } \\
\text { of Rs. } \\
50000 \text { has } \\
\text { been } \\
\text { dispersed as } \\
\text { group loan } \\
\text { at interest } \\
\text { rate of } \\
24.91 \% \text { p.a. }\end{array}$ & $\begin{array}{l}\text { Retail financing } \\
\text { provided for } \\
\text { products like } \\
\text { two wheelers, } \\
\text { consumer } \\
\text { durables, office } \\
\text { equipment } \\
\text { etc.at } 26 \% \\
\text { interest rate } \\
\text { and } 1 \% \\
\text { processing fees }\end{array}$ & $\begin{array}{l}\text { A three day } \\
\text { Compulsory } \\
\text { Group } \\
\text { Training } \\
\text { (CGT) is } \\
\text { provided to } \\
\text { the clients } \\
\text { followed by a } \\
\text { Group } \\
\text { Recognition } \\
\text { Test (GRT) } \\
\text { undertaken } \\
\text { by Branch } \\
\text { Manager }\end{array}$ & $\begin{array}{l}\text { Compulsory } \\
\text { Group } \\
\text { Training(CG } \\
\text { T) and Group } \\
\text { Recognition } \\
\text { Test(GRT) is } \\
\text { conducted on } \\
\text { the clients } \\
\text { before } \\
\text { lending }\end{array}$ & $\begin{array}{l}\text { JLG Model } \\
\text { followed. } \\
\text { CGT and } \\
\text { GRT } \\
\text { undertaken } \\
\text { for } \\
\text { prospective } \\
\text { clients. }\end{array}$ & $\begin{array}{l}\text { Joint liability } \\
\text { group loans } \\
\text { ranging from } \\
\text { Rs. 15,000 to } \\
\text { Rs. 80,000 } \\
\text { repayable over } \\
\text { a period of } 12- \\
36 \text { months at } \\
25.35 \% \text { rate of } \\
\text { interest p.a. }\end{array}$ & $\begin{array}{l}\text { Three day } \\
\text { training } \\
\text { program is } \\
\text { conducted } \\
\text { before } \\
\text { providing } \\
\text { group loans } \\
\text { to women } \\
\text { borrowers }\end{array}$ \\
\hline
\end{tabular}




\begin{tabular}{|c|c|c|c|c|c|c|c|}
\hline $\begin{array}{l}\text { Products \& } \\
\text { Services }\end{array}$ & $\begin{array}{l}\text { Income } \\
\text { generating } \\
\text { group loans } \\
\text { (JLG) for } \\
\text { varied } \\
\text { purposes } \\
\text { include } \\
\text { cattle, } \\
\text { agriculture, } \\
\text { materials, } \\
\text { dairy and } \\
\text { starting of a } \\
\text { small scale } \\
\text { business. }\end{array}$ & $\begin{array}{l}\text { Provide } \\
\text { individual and } \\
\text { group loans to } \\
\text { their clients for } \\
\text { various income } \\
\text { generating } \\
\text { activities which } \\
\text { include } \\
\text { manufacturing, } \\
\text { dairy and } \\
\text { livestock, } \\
\text { trading, } \\
\text { services, retail } \\
\text { and agriculture }\end{array}$ & $\begin{array}{l}\text { Various types } \\
\text { of loan } \\
\text { products are } \\
\text { offered at } \\
\text { Fusion like } \\
\text { Income } \\
\text { Generation, } \\
\text { Top up, } \\
\text { Emergency } \\
\text { and } \\
\text { Sanjivani. }\end{array}$ & $\begin{array}{l}\text { Income } \\
\text { generating } \\
\text { loan, Water } \\
\text { and } \\
\text { Sanitation } \\
\text { loan and } \\
\text { Solar loan }\end{array}$ & $\begin{array}{l}\text { Four loan } \\
\text { products are } \\
\text { offered } \\
\text { namely } \\
\text { SaijaKarobar } \\
\text { Rin (SKR), } \\
\text { SaijaMahila } \\
\text { Rin (SMR), } \\
\text { SaijaVridhi } \\
\text { Rin (SVR) } \\
\text { and Saija } \\
\text { Phone Rin } \\
\text { (SPR) }\end{array}$ & $\begin{array}{l}\text { Income } \\
\text { generating } \\
\text { microfinance } \\
\text { loans ranging } \\
\text { from Rs. } \\
15,000 \text { to Rs. } \\
80,000 \\
\text { repayable over } \\
\text { a period of } 12- \\
36 \text { months. }\end{array}$ & $\begin{array}{l}\text { Three } \\
\text { different } \\
\text { kinds of } \\
\text { loan } \\
\text { products are } \\
\text { offered } \\
\text { namely } \\
\text { Unnati, } \\
\text { Pragati and } \\
\text { Samriddhi }\end{array}$ \\
\hline $\begin{array}{l}\text { Geographic } \\
\text { al Spread }\end{array}$ & $\begin{array}{l}\text { Currently } \\
\text { operational } \\
\text { in } 7 \text { states of } \\
\text { the country }\end{array}$ & $\begin{array}{l}\text { Present in } 6 \\
\text { states and } \\
\text { union } \\
\text { territories } \\
\text { across the } \\
\text { Northern } \\
\text { region of the } \\
\text { country }\end{array}$ & $\begin{array}{l}\text { Operational } \\
\text { in } 14 \text { states } \\
\text { through } 180 \\
\text { districts and } \\
316 \text { branches }\end{array}$ & $\begin{array}{l}\text { Spread its } \\
\text { operations } \\
\text { across } 16 \\
\text { States and } \\
\text { UTs with } 634 \\
\text { branches }\end{array}$ & $\begin{array}{l}\text { Working in } \\
\text { three } \\
\text { operational } \\
\text { States } \\
\text { through } 64 \\
\text { branches and } \\
37 \text { districts }\end{array}$ & $\begin{array}{l}\text { Shikhar has } \\
\text { extended } \\
\text { operations to } 4 \\
\text { States and } 176 \\
\text { Locations } \\
\text { covered by } 20 \\
\text { branches }\end{array}$ & $\begin{array}{l}\text { SVCL is } \\
\text { operational } \\
\text { in } 9 \text { states } \\
\text { through } 227 \\
\text { locations }\end{array}$ \\
\hline
\end{tabular}

\section{Result}

The results of the dummy regressions reveal that size has no significant influence on the various financial performance indicators of the sample micro finance institutions. In all the regressions that we have run, the $\mathrm{p}$-value of the coefficient of dummy variable (representing the explanatory variable in our case) is greater than 0.05. Hence, we do not reject our null hypothesis that, there is no significant difference in the performance of selected micro finance institutions based upon their categorization of size.

The analysis of rankings of the different sample micro finance reveals that Fusion has poor ranking for loan quality while as rest of the institutions secure a moderate ranking between 3 and 4. Similarly, Capital trust and Saija get nearly poor ranking for operational efficiency, while others get a moderate ranking between 3 and 4. Satin, Capital trust and SVCL obtain close to poor ranking, while others get a moderate ranking between 3 and 4 for portfolio quality.

Overall, Satin, SVCL and Capital Trust secure nearly poor ranking while as others obtain a moderate ranking between 3 and 4 .

Table 1: Summary of the results of Dummy Regression

\begin{tabular}{|c|c|c|c|c|c|c|c|}
\hline Loan Quality Ranking & Satin & Saija & Capital Trust & Altura & Fusion & SVCL & Shikhar \\
\hline $\begin{array}{l}\text { Average loan per borrower (lower the } \\
\text { better) }\end{array}$ & 1 & 2 & 3 & 4 & 5 & 6 & 7 \\
\hline $\begin{array}{l}\text { loan distributed to gross loan (higher } \\
\text { the better) }\end{array}$ & 7 & 6 & 3 & 4 & 5 & 2 & 1 \\
\hline $\begin{array}{l}\text { proportion of defaulted accounts in } \\
\text { active accounts (lower the best) }\end{array}$ & 1 & 3 & 6 & 5 & 7 & 4 & 2 \\
\hline Overall Loan Quality Ranking & 3 & 4 & 4 & 4 & 6 & 4 & 3 \\
\hline Operational Efficiency Ranking & Satin & Saija & Capital Trust & Altura & Fusion & SVCL & Shikhar \\
\hline $\begin{array}{l}\text { manager to field staff ratio (lower the } \\
\text { betfer) }\end{array}$ & 7 & 2 & 6 & 4 & 1 & 3 & \\
\hline Rate interest (lower the better) & 1 & 5 & 7 & 2 & 3 & 4 & 6 \\
\hline $\begin{array}{l}\text { field aff per branch (lower the } \\
\text { bette }\end{array}$ & 5 & 7 & 3 & 2 & 4 & 6 & 1 \\
\hline
\end{tabular}




\begin{tabular}{|c|c|c|c|c|c|c|c|}
\hline $\begin{array}{l}\text { average loan per field staff (higher the } \\
\text { better) }\end{array}$ & 1 & 6 & 7 & 5 & 3 & 4 & 2 \\
\hline $\begin{array}{l}\text { Overall Operational Efficiency } \\
\text { Ranking }\end{array}$ & 4 & 5 & 6 & 3 & 3 & 4 & 4 \\
\hline Portfolio Quality Ranking & Satin & Saija & Capital Trust & Altura & Fusion & SVCL & Shikhar \\
\hline $\begin{array}{l}\text { Portfolio at Risk past due over } 30 \text { days } \\
\text { (lower the better) }\end{array}$ & 7 & 4 & 6 & 1 & 2 & 5 & 3 \\
\hline $\begin{array}{l}\text { Portfolio at Risk past due over } 90 \text { days } \\
\text { (lower the better) }\end{array}$ & 7 & 4 & 5 & 1 & 2 & 6 & 3 \\
\hline Overall Portfolio Quality Ranking & 7 & 4 & 6 & 1 & 2 & 6 & 3 \\
\hline Overall Performance Rankings & 5 & 4 & 5 & 3 & 3 & 5 & 3 \\
\hline
\end{tabular}

Table 2: Summary of Performance Rankings

\begin{tabular}{|c|c|c|c|c|c|}
\hline Model & & coffecient & t Stat & p-value & $\mathbf{R}^{\wedge} \mathbf{2}$ \\
\hline \multirow[t]{2}{*}{ avg loan $=\mathrm{f}($ size $)$} & intercept & 13126.74419 & 2.791074 & 0.038396 & 0.0655 \\
\hline & $\begin{array}{l}\text { size } \\
\text { dummy }\end{array}$ & -4253.00381 & -0.592 & 0.579604 & \\
\hline \multirow[t]{2}{*}{$\begin{array}{l}\text { loan distribute to gross } \\
\text { loan=f(size) }\end{array}$} & intercept & 1.085428611 & 3.077457 & 0.027549 & 0.093657 \\
\hline & $\begin{array}{l}\text { size } \\
\text { dummy }\end{array}$ & -0.38726243 & -0.7188 & 0.504445 & \\
\hline \multirow[t]{2}{*}{$\begin{array}{l}\text { proportion of defaulted loans in } \\
\text { active borrowers }=f(\text { size })\end{array}$} & intercept & 0.063313953 & 2.097906 & 0.089992 & 0.028788 \\
\hline & $\begin{array}{l}\text { size } \\
\text { dummy }\end{array}$ & 0.017747326 & 0.384974 & 0.716089 & \\
\hline \multirow[t]{2}{*}{ manager to field staff ratio $=\mathrm{f}($ size $)$} & intercept & 0.224900798 & 1.908462 & 0.114612 & 0.001588 \\
\hline & $\begin{array}{l}\text { size } \\
\text { dummy }\end{array}$ & -0.01605143 & -0.08917 & 0.932409 & \\
\hline \multirow[t]{2}{*}{ rate of interest $=\mathrm{f}($ size $)$} & intercept & 0.250875 & 73.15858 & 9.04E-09 & 0.25624 \\
\hline & $\begin{array}{l}\text { size } \\
\text { dummy }\end{array}$ & -0.006875 & -1.31248 & 0.246374 & \\
\hline \multirow[t]{2}{*}{ Field staff per branch $=f($ size $)$} & intercept & 5.38791856 & 3.831648 & 0.012227 & 0.015966 \\
\hline & $\begin{array}{l}\text { size } \\
\text { dummy }\end{array}$ & 0.611795055 & 0.284828 & 0.787197 & \\
\hline \multirow[t]{2}{*}{ Average loan per field staff $=\mathrm{f}($ size $)$} & intercept & 162.1745678 & 0.426223 & 0.687672 & 0.222446 \\
\hline & $\begin{array}{l}\text { size } \\
\text { dummy }\end{array}$ & 695.1308877 & 1.196003 & 0.285314 & \\
\hline \multirow[t]{2}{*}{ Portfolio at risk $>$ 3odays $=\mathrm{f}($ size $)$} & intercept & 6.6975 & 1.348133 & 0.235467 & 0.115742 \\
\hline & $\begin{array}{l}\text { size } \\
\text { dummy }\end{array}$ & 6.139166667 & 0.808986 & 0.455279 & \\
\hline \multirow[t]{2}{*}{ Portfolio at risk $>$ 9odays $=\mathrm{f}($ size $)$} & intercept & 3.54 & 1.379811 & 0.226156 & 0.18247 \\
\hline & $\begin{array}{l}\text { size } \\
\text { dummy }\end{array}$ & 4.14 & 1.0564 & 0.339132 & \\
\hline
\end{tabular}

Source: Compiled by Authors

\section{Discussions}

The findings indicate the dismal state of micro finance institutions operating in New Delhi. The 15,000 crores Industry hold great potential to serve the financially needy, but are required to revisit their strategies to approach their customers. The State government needs to learn and pour in some funds to render financial help to these institutions so that they are able to enhance their financial performance. One major reason of the poor performance can be traced back to demonetization witnessed by the country on November 8,2016 . The clients 
suddenly ran out of hard cash and failed to repay the loan amounts timely. The Institutions are still trying to recover from the sudden blown received at their end. The researcher would also like to mention that due to the sample size being quite limited, no generalization of the result can be done on other parts of the country. Further research can be undertaken from the point of view of the clients to understand what problems are faced by them and the reasons as to why they prefer one institution over another for their loan grant. 


\section{References}

i. Ahlin, C., Lin, J. \& Maio, M., 2011. Where does microfinance flourish? Microfinance institution performance in macroeconomic context. Journal of Development Economics, 95(2), pp. 105120.

ii. Alem, M. \& Townsend, R., 2014. An evaluation of financial institutions: Impact on consumption and investment using panel data and the theory of risk-bearing. Journal of Econometrics, $183(1)$, p. $91=103$.

iii. Altura Financials, n.d. Altura Finacials. [Online] Available at: ttp://www.alturafinancials.com/

iv. Ambedkar, B. \& Uni, M., 2016. Microfinance initiatives in india, Nepal: s.n.

v. $\quad$ Area, S., Jeet, S. \& Marg, S., n.d. Directory of Microfinance Institutions ( MFIs ) in India, s.l.: Directory of Microfinance Institutions ( MFIs ).

vi. Babu, M. M. \& Kulshreshtha, P., 2014. Productivity Change and Technical Efficiency in Indian Microfinance Institutions. Studies in Microeconomics, 2(2), pp. 165-200.

vii. Bassem, B., 2009. Governance and performance of microfinance institutions in Mediterranean Countries. Journal of Business Economics and Management, 10(1), pp. 31-43.

viii. Batra, V., 2011. The State of Microfinance in India: Emergence, Delivery Models and Issues. AIUB-Working Paper No. AIUB-BUS-ECON-2O11-O2, 2, 1-26., s.l.: s.n.

ix. Becchetti, L. \& Castriota, S., 2011. Post Tsunami intervention and the socioeconomic well-being of microfinance borrowers. World Development, 39(6), pp. 898-912.

x. Belvisi, M. \& Pianeti, G. R., 2016. Article information. Dynamic Factor Models, Volume 35, pp. 317-360.

xi. Bos, J. \& Millone, M., 2015. Practice What You Preach: Microfinance Business Models and Operational Efficiency. World Development, Volume 70, pp. 28-42.

xii. Capital Trust, n.d. [Online] Available at: http://capital-trust.com/

xiii. Chakrabarti, R., 2005. The Indian Microfinance Experience - Accomplishments and Challenges, s.l.: SSRN eLibrary..

xiv. Chao-Béroff, R. et al., 200o. A Comparative Analysis of Member-Based Microfinance Institutions In East And West Africa, (March), 1-33., s.l.: s.n.

xv. Copestake, J., 2007. Mainstreaming Microfinance: Social Performance Management or Mission Drift?. World Development, 35(10), pp. 1721-1738.

xvi. Correspondents, B., n.d. Business Correspondents in India, Nepal: s.n.

xvii. Cull, R., Demirgüç-Kunt, A. \& Morduch, J., 2011. Does Regulatory Supervision Curtail Microfinance Profitability and Outreach?. World Development, 39(6), pp. 949-965.

xviii. Directory of Microfinance Institutions ( MFIs ), 2016. Directory of Microfinance Institutions ( MFIs ), s.l.: Directory of Microfinance Institutions ( MFIs ).

xix. Emeni, F., 2008. Micro Finance Institutions (MFIs) in Nigeria-Problems and Prospects: Questionnaire Survey Findings. Journal of Financial Management and Analysis, 21(1), pp. 6976.

xx. Fell, J., 2005. Assessing Financial Stability: Exploring the Boundaries of Analysis. National Institute Economic Review, 192(192), pp. 107-117.

xxi. Ferro-Luzzi, G. \& Weber, S., 2006. Measuring the Performance of Microfinance institutions. SSRN Electronic Journal, pp. 1-17.

xxii. Field, E. \& Pande, R., 2008. Repayment Frequency and Defualt in Microfinance:Evidence from India. Journal of the European Economic Association, Volume 6, pp. 501-509.

xxiii. Forster, N. \& Rockart, J., 1989. Critical Success Factors: An annotated bibliography. MIT Sloan Review, Volume 191, pp. 3041-3089. 
xxiv. Fusion Microfinance, n.d. Fusion Microfinnace. [Online]

Available at: http://fusionmicrofinance.com/

xxv. Gupta, P., Chawla, P. \& Harkawat, P., 2012. Measuring Performance of Microfinance Institutions in India. Annamalai International Journal of Business Studies and Research, 4(1), pp. 14-23.

xxvi. Hartarska, V., 2005. Governance and performance of microfinance institutions in Central and Eastern Europe and the Newly Independent States.. World Development, 33(10), pp. 16271643.

xxvii. Hartungi, R., 2007. Understanding the success factors of micro-finance institution in a developing country. International Journal of Social Economics, 34(6), pp. 388-401.

xxviii. Hermes, N. \& Lensink, R., 2011. Its Impact, Outreach, and sustainability. World Development, 39(6), pp. 875-881.

xxix. Hermes, N., Lensink, R. \& Meesters, A., 2011. Outreach and Efficiency of Microfinance institutions. World Development, 39(6), pp. 938-948.

xxx. Hudon, M. \& Traca, D., 2011. On the Efficiency Effects of Subsidies in Microfinance: An Empirical Inquiry. World Development, 39(6), pp. 966-973.

xxxi. Hudon, M. \& Traca, D., 2011. Subsidies and sustainability in microfinance. World Development, 39(6), pp. 966-973.

xxxii. Imai, K., Arun, T. \& Annim, S., 2010. Microfinance and Household Poverty Reduction: New Evidence from India. World Development, 38(12), pp. 1760-1774.

xxxiii. K.M.S, P., Suresh, A. \& Vijayashree, L., 2012. Micro Finance and its Risk. Management Practices in India: A Conceptual Study, 10(1), pp. 13-24.

xxxiv. Kaur, P., 2016. Efficiency of Microfinance Institutions in India: Are They Reaching the Poorest of the Poor?. The Journal of Business Perspective, 20(1), pp. 54-65.

xxxv. Kereta, B., 2007. Outreach and Financial Performance Analysis of Microfinance Institutions in Ethiopia. Addis Ababa, African Economic Conference. United Nations Conference Center (UNCC), Addis Ababa, Ethiopia 15-17 November 2007.

xxxvi. Koveos, P. \& Randhawa, D., 2004. Financial services for the poor: assessing microfinance institutions. Manegerial Finance, 30(9), pp. 70-95.

xxxvii. Lafourcade, A., Isern, J., Mwangi, P. \& Brown, M., 2005. Overview of the Outreach and Financial Performance of Microfinance Institutions in Africa Survey of African microfinance institutions, s.l.: Africa Survey of African microfinance institutions.

xxxviii. Lahkar, R. \& Pingali, V., 2016. Expansion and welfare in microfinance: A screening model. Economic Modelling, Volume 53, pp. 1-7.

xxxix. Littlefield, B., Morduch, J. \& Hashemi, S., 2003. Is Microfinance an Effective Strategy to Reach the Millennium Development Goals?. Focus Note, Volume 24, pp. 1-11.

xl. Louis, A., Seret, A. \& Baesens, B., 2013. Financial Efficiency and Social Impact of Microfinance Institutions Using Self-Organizing Maps. World Development, Volume 46, pp. 197-210.

xli. Matin, I., Hulme, D. \& Rutherford, S., 2002. Finance for the poor: From microcredit. Journal of International Development, 14(2), pp. 273-294.

xlii. Mayoux, L., 2000. Micro-finance and empowerment of women: a review of the key issues, s.l.: ILO Social Finance Unit..

xliii. Mayoux, L., 2001. Tackling the Down Side: Social Capital, Women's Empowerment and MicroFinance in Cameroon. Development and Change, Volume 32, pp. 435-364.

xliv. McIntosh, C., Villaran, G. \& Wydick, B., 2011. Microfinance and home improvement: Using retrospective panel data to measure program effects on discrete. World Development , 39(6), pp. 922-937. 
xlv. Mersland, R., 2009. The Cost of Ownership in Microfinance Organizations.. World Development, 37(2), pp. 469-478.

xlvi. $\quad$ Mersland, R. \& Strom, R. O., 2009. Performance and governance in microfinance institutions. Journal of Banking and Finance, 33(4), pp. 662-669.

xlvii. Meyer, R., 2002. Track record of financial institutions in assisting the poor in Asia, ABD Institute Research Paper, 42.: s.n.

xlviii. $\quad$ MFI in India, n.d. MFI in India. [Online]

Available at: http://mfinindia.org/resource-center/mfin-publications/

xlix. Monne, J., Louche, C. \& Villa, C., 2016. Rational Herding toward the Poor: Evidence from Location Decisions of Microfinance Institutions within Pakistan.. World Development, Volume 84, pp. 266-281.

1. Mwenda, K. \& Muuka, G., 2004. Towards best practices for micro finance institutional engagement in African rural areas: Selected cases and agenda for action.. International Journal of Social Economics, 31(1/2), pp. 143-158.

li. NABARD, 2012. Status of Microfinance in India 2011-12. 1(C), pp. 160-161.

lii. Narwal, K. \& Yadav, M., 2014. Impact of Characteristics on Outreach and Profitability of Microfinance Institution in India., s.l.: s.n.

liii. Nasir, S., 2013. Microfinance in India: Contemporary Issues and Challenges.. Middle-East Journal of Scientific Research, 15(2), pp. 191-199.

liv. Navajas, et al., 2000. "Microcredit and the Poorest of the Poor: Theory and Evidence from Bolivia”. World Development, 28(2), pp. 333-346.

lv. Paul, S., 2014. Creditworthiness of a Borrower and the Selection Process in Microfinance: A Case Study from the Urban Slums of India. Margin: The Journal of Applied Economic Research, 8(1), pp. 59-75.

lvi. Pellegrina, L. D., 2011. Microfinance and investment: A comparison with bank and informal lending.. World Development, 39(6), pp. 882-897.

lvii. Porkodi, S., 2013. Role of Micro Finance and Self Help Groups in Financial Inclusion. 2(3), pp. 137-149.

lviii. Richard, K., Segun, S. \& Anjugam, M., 2013. Measuring The Efficiency Of SubSaharan Africa ' S Microfinance Institutions And Its Drivers. Annals of Public and Cooperative Economics, 84(4), pp. 399-422.

lix. Robinson \& Marguerite, S., 2001. The Microfinance Revolution: Sustainable Finance for the Poor, Washington DC: World Bank and Open Society Institute.

lx. $\quad$ Rooyen, C., Stewart, R. \& Wet, T., 2012. The Impact of Microfinance in Sub-Saharan Africa: A Systematic Review of the Evidence. World Development, 40(11), pp. 2249-2262.

lxi. $\quad$ Sa-Dhan, 2015. The Bharat Microfinance Report 2015. Microfinance Report, p. 122.

lxii. Saija, n.d. Saija. [Online] Available at: http://saija.in/

lxiii. Sarap, A., 2014. Success and Constraints of Group Lending Programs: Evidence from the Working of Micro-Credit Institutions in Odisha. South Asian Journal of Management, 21(1), pp. 65-83.

lxiv. Saravanan, S. \& Dash, D., 2017. Growth and distribution of microfinance in India: A panel data analysis. Theoretical and Applied Economics, 24(1610), pp. 127-146.

lxv. Sarkar, A., 2006. Savings-led Micro-finance to Bank the Unbankables: Sharing of Global experience. Global Business Review, 7(2), pp. 271-295.

lxvi. Satin Credit Care, n.d. Satin Credit Care. [Online]

Available at: https://www.satincreditcare.com/ 
lxvii. SCVL, n.d. SCVL. [Online] Available at: http://www.svcl.in/

lxviii. Shahriar, A., Schwarz, S. \& Newman, A., 2015. Profit orientation of microfinance institutions and provision of financial capital to business start-ups.. International Small Business Journal, Volume 1, pp. 1-21.

lxix. Shete, N., 1999. Alternative Models Of Micro-Finance: Experiences Of Indian Commercial Banks, Bergamo: Giordano Dell-Amore Foundation Research Center on International Cooperation of the University of Bergamo.

lxx. Shikharfin, n.d. Shikharfin. [Online] Available at: http://shikharfin.com/

lxxi. Stiglitz, Joseph, E. \& Weiss, A., 1981. Credit Rationing in Markets with Imperfect Information.. American Economic Review, 71(3), pp. 393-410.

lxxii. Tchuigoua, H. T., 2016. Buffer capital in microfinance institutions. Journal of of Business Research, 69(9), pp. 3523-3537.

lxxiii. Temu \& Andrew, E., 1999. The Kilimanjaro Co-Operative Bank : A Potentially Sustainable Rural Financial Institution Model For Sub-Saharan Africa. African Review of Money Finance and Banking, pp. 49-76.

lxxiv. $\quad$ Verma, R., 2014. Original Article Microfinance in India. 2(7), pp. 1-10.

lxxv. Vik, E., 2010. In numbers we trust: measuring impact or institutional performance?. Perspectives on Global Development and Technology, 9(3-4), pp. 292-326.

lxxvi. Widiarto, I. \& Emrouznejad, A., 2015. Social and financial efficiency of Islamic microfinance institutions: A Data Envelopment Analysis application. Socio-Economic Planning Sciences, Volume 50, pp. 1-17.

lxxvii. Wijesiri, M., Vigan, L. \& Meoli, M., 2015. Efficiency of microfinance institutions in Sri Lanka: A two-stage double bootstrap DEA approach. Economic Modelling, Volume 47, pp. 74-83.

lxxviii. Wydick, B., Karp, H. \& Hilliker, S., 2011. Social networks, neighborhood effects and credit access. World Development, 39(6), pp. 974-982. 